\title{
Spraying Time of Nano Zinc Concentration in Relation to Yield and Quality of Egyptian Cotton $c v$. Giza 94
}

\author{
Abo-Baker E. M. Gadalla ${ }^{1}$ and El-Saeed M. M. El-Gedwy ${ }^{2}$ \\ ${ }^{1}$ Cotton Research Institute - Agricultural Research Center - Giza - Egypt. \\ ${ }^{2}$ Agronomy Department - Faculty of Agriculture - Benha University - Egypt. \\ Corresponding author: alsaeed.algedwy@fagr.bu.edu.eg
}

\begin{abstract}
Two field experiments were conducted on a clay soil at the Farm of Sakha Agricultural Research Station (Kafr El-Sheikh Governorate), Agricultural Research Center, Giza, Egypt, during growing 2016 and 2017 seasons, to investigate the effect of foliar feeding by four concentrations of nano zinc fertilizer (distilled water \{control\}, $100 \mathrm{ppm}, 200 \mathrm{ppm}$ and $300 \mathrm{ppm}$ ) at three foliar application times (at the squaring stage, at the flowering initiation stage and at the top of flowering stage) on growth, yield components, yield and some fiber properties for the Egyptian cotton $c v$. Giza 94. The experimental design was split plot design with four replicates. The four concentrations of nano zinc fertilizer were randomly assigned for main plots and the three times of foliar application were randomly assigned for sub-plots. Results showed that, mean values of plant height $(\mathrm{cm})$, No. of sympodial branches/plant, No. of opened bolls/plant, boll weight $(\mathrm{g})$, seed index $(\mathrm{g})$, lint percentage $(\%)$, seed cotton yield/fed (ken), lint cotton yield/fed (ken), upper half mean length (mm), fiber strength (g/tex), micronaire value and fiber maturity ratio were significantly increased with increasing zinc concentration in the form of nano fertilizer compared to plants receiving distilled water during the both seasons, cotton plants receiving the highest concentration of nano zinc fertilizer (300 ppm) gave the maximum mean values of above traits during the both seasons. Foliar feeding at the flowering initiation stage significantly achieved maximum estimates in mean values of plant height $(\mathrm{cm})$, No. of sympodial branches/plant, No. of opened bolls/plant, seed cotton yield/fed (ken), lint cotton yield/fed (ken), upper half mean length (mm) and fiber strength (g/tex) followed by foliar feeding at the top of flowering stage then foliar feeding at the squaring stage during the both seasons. Cotton plants receiving the highest concentration of nano zinc fertilizer (300 ppm) at the flowering initiation stage significantly recorded the highest mean values of No. of sympodial branches/plant, No. of opened bolls/plant, seed cotton yield/fed (ken), lint cotton yield/fed (ken), upper half mean length (mm) and fiber strength $(\mathrm{g} / \mathrm{tex})$ during the both seasons, where this combination is the best treatment for good yield and fiber properties traits for Egyptian cotton $c v$. Giza 94 under the conditions of Kafr El-Sheikh location.
\end{abstract}

Key words: Egyptian cotton, nano zinc fertilizer, foliar application time, fiber properties

\section{Introduction}

Cotton Cotton is considered the main fiber crop in Egypt as well as the world. Egyptian statistics indicates decreasing of cotton cultivated area from 851283 fed on 1991 year to about 216554 fed on 2017 year, with decreasing percent of about $74.56 \%$ that lead to a decrease in cotton production from 5826000 kentars on 1991 year to about 1357000 kentars on 2017 year, with decreasing percent by about $76.71 \%$ in 2017 year comparing with the year 1991 (Egyptian Cotton Gazette, 2017).

Foliar feeding of micronutrients plays an important role in changing growth and physiological characteristics of cotton. In optimizing fertilization strategies, inclusion of foliar application improves fertilizer use efficiency and reduces environmental pollution. Foliar application of micronutrient mixtures during flower and boll development stages have been shown to be effective in efficient utilization of nutrients by cotton and thereby reduce boll shedding and increase the yield (Radhika et al. 2013).

Crop plants are prone to infection by several pathogens which cause diseases that affect the production and economy of these crops. Farmers tend to use traditional control methods such as; chemical pesticides and bioagents which are non-ecofriendly and not easily produced/applied, respectively. Nanoparticles have sizes less than $100 \mathrm{~nm}$ and are considered for several applications including; agriculture, food technology, pharmaceuticals in addition to protection of environment. Availability, low-cost and nonphytotoxicity of nanoparticles are the main prerequisites for their application in the field of agriculture (Madbouly 2018).

Crop yield significantly increases with the use of micronutrients such as zinc, iron, boron, copper, manganese, etc. Zinc has an important metabolically role in plants growth and development and is therefore called an essential trace element or a micronutrient. Zinc is uptake and transfers the form of $\mathrm{Zn}^{2+}$ in plants and is an essential nutrient that has particular physiological functions in all living systems, such as the maintenance of structural and functional integrity of biological membranes and facilitation of protein synthesis and gene expression, enzymes structure, energy production and Krebs cycle; also has a positive impact on crops yield; therefore crops quantitative and qualitative yield is 
strongly dependent on zinc in the soil (Efe \& Yarpuz 2011 and Mousavi et al. 2013).

Sawan et al. (2008) found that foliar feeding by zinc at rate of $57.6 \mathrm{~g} / \mathrm{ha}$ in chelated form (ethylenediaminetetraacetic acid) at two times (70 and 85 days after sowing) during the square initiation and boll setting stage improved mean values of No. of opened bolls/plant, boll weight, seed index, lint percentage, seed cotton yield/fed, lint cotton yield/fed, upper half mean length, fiber strength and micronaire value of Egyptian cotton $c v$. Giza 86.

Ali et al. 2011, Emara 2016 and El-Gedwy et al. 2018 recorded that application twice of Zinc Sulphate $\left(\mathrm{Zn} \mathrm{So} .7 \mathrm{H}_{2} \mathrm{O}\right)$ by concentration of $0.4 \%$, as foliar spray; it began at the beginning of flowering and 15 days later gave greatest mean values of plant height, No. of sympodial branches/plant, No. of opened bolls/plant, seed cotton yield/plant, boll weight, lint $\%$, lint cotton yield/plant, seed index, seed cotton yield/fed, lint cotton yield/fed, upper half mean length, length uniformity index, fiber strength, fiber elongation $\%$, micronaire value and fiber maturity ratio in the both seasons.

Abdallah and Mohamed (2013) found that foliar feeding with zinc at concentration of $2 \mathrm{~g} /$ liter and spraying took place twice, at the beginning of the flowering stage and 15 days later led to increase men values of plant height, No. of sympodial branches/plant, No. of opened bolls/ plant, boll weight, seed index, seed cotton yield/fed, earliness $\%$, lint percentage, fiber length, fiber strength and fiber fineness of Egyptian cotton.

Siskani et al. (2017) found that spraying twice with nano zinc at a rate of $500 \mathrm{ppm}$ led to $12.5 \%$ increase in cotton lint yield that control (tap water).

Venkatachalam et al. (2017) study focused on applying zinc oxide nanoparticles (nano $\mathrm{ZnO}$ ) carrying phycomolecule ligands as novel plant growth promoters to increase crop production. This investigation examined the effect of nano $\mathrm{ZnO}$ on growth characteristics of cotton (Gossypium hirsutum L.) and associated biochemical changes, following growth in a range of concentrations of nano $\mathrm{ZnO}$ (25$200 \mathrm{mg} / \mathrm{l}$ ) in presence of $100 \mathrm{mM}$ of $(\mathrm{P})$. Cotton plants increased in growth and total biomass by 130.6 $\%$ and $131 \%$, respectively, compared with control. Moreover, considerable increase in the level of chlorophyll a $(141.6 \%)$, b (134.7\%), carotenoids $(138.6 \%)$, and total soluble proteins $(179.4 \%)$ were recorded; in addition to significant reduction $(68 \%)$ in the level of malondialdehyde (MDA) in cotton leaves. These promising results could be attributed to the interaction of bioengineered nano $\mathrm{ZnO}$ with cotton meristematic cells thus stimulated biochemical reactions that led to increase of biomass.

Hussein and Abou-Baker (2018) found that mean values of boll weight $(\mathrm{g})$ was significantly increased by increased concentrations of nano- $\mathrm{Zn}$ from zero (distilled water) to 100 and $200 \mathrm{ppm}$ at three weeks of sowing and the second application was two weeks after the first application.

By considering all these points, the research was conducted to study the effect of spraying time of nano zinc concentration in relation to growth traits, yield components, yield and fiber properties of Egyptian cotton $c v$. Giza 94.

\section{Materials and Methods}

Two field experiments were carried out at the Farm of Sakha Agricultural Research Station (Kafr El-Sheikh Governorate), Agricultural Research Center, Giza, Egypt, during the two growing seasons 2016 and 2017. This study aims to investigate the efficiency effect of foliar feeding by some concentrations of nano zinc fertilizer at different foliar application times on growth traits, yield components, yield and some fiber properties for the Egyptian cotton (Gossypium barbadense L.), cv. Giza 94.

Soil texture of the experimental site was clay. The chemical and mechanical properties of the experimental soil were determined according to standard methods outlined by Jackson (1973). Available manganese, iron, zinc and copper were determined using Atomic Absorption Spectrophotometer (AAS) after extracting the soil with DTPA as proposed by Lindsay and Norvell (1978) and represented in Table 1 in each of the two growing seasons.

Table 1. Chemical and mechanical analysis of the experimental soil units of the two growing seasons (2016 and 2017).

\begin{tabular}{lcc}
\hline \multirow{2}{*}{ Properties } & \multicolumn{2}{c}{ Season } \\
\cline { 2 - 3 } Chemical analysis & $\mathbf{2 0 1 6}$ & $\mathbf{2 0 1 7}$ \\
\hline E.C. & 3.50 & 4.22 \\
pH (1 :2.5) & 8.92 & 8.78 \\
Ca Co3 \% & 3.21 & 2.86 \\
O.M \% & 1.82 & 1.91 \\
N \% ( total) & 0.119 & 0.125 \\
Available N (ppm) & 62.15 & 69.51 \\
P \% ( total) & 0.065 & 0.079 \\
Available P (ppm) & 11.32 & 14.15 \\
K \% ( total) & 0.24 & 0.31 \\
Available K (ppm) & 340.23 & 400.55 \\
Available Mn (ppm) & 3.57 & 4.59 \\
Available Fe (ppm) & 6.95 & 8.57 \\
Available Zn (ppm) & 0.65 & 0.49 \\
Available Cu (ppm) & 2.56 & 1.95 \\
\hline Sand \% & \multicolumn{2}{c}{} \\
Silt \% & 23.42 & 19.70 \\
Clay \% & 31.32 & 33.58 \\
Texture grade & 45.26 & 46.72 \\
& Clay & Clay \\
\hline
\end{tabular}

Every experiment included twelve treatments which were combination of the four concentrations of 
nano zinc fertilizer and three times of foliar application, the levels of these factors were as follows:

\section{A- Four concentrations of nano zinc fertilizer treatments: \\ 1- Control (Distilled Water). \\ 2- $100 \mathrm{ppm}$. \\ 3- $200 \mathrm{ppm}$. \\ 4- $300 \mathrm{ppm}$.}

\section{B- Three times of foliar application treatments:}

1- At the squaring stage.

2- At the flowering initiation.

3- At the top of flowering.

\section{Preparation of nano zinc fertilizer:}

Nano zinc fertilizer was prepared in laboratory by ball-milling (Photon Company, Egypt). Portion of $100 \mathrm{~g}$ of individual zinc fertilizer were placed in a stainless steel canister with metal balls. The canister was placed on the ball-milling machine and stirred for 26 hours at speed of $1000 \mathrm{rpm} /$ minute, then a sample from milled zinc was collected and submitted to Transmission Electron Microscopy (TEM) laboratory for investigation and measuring the size of the zinc fertilizer particle. The size and morphology of nano zinc was studied using JEOL transmission electron microscope (JEM-1400 TEM, Japan). A drop of well dispersed nano zinc dispersion was placed onto the amorphous carbon-coated 200 mesh carbon grid, followed by drying the sample at ambient temperature, before loading into the microscope (Wang et al. 2016). Surfactant (super film $(\circledR)$ was added according to the recommendation of its label. Standard methods for spraying were followed to avoid osmosis effect on plants. The foliar application was carried out between 09:00 and 11:00 a.m., using a knapsack sprayer by foliar solution rate was 600 liter feddan.

The preceding winter crop in the two seasons was Egyptian clover (Trifolium alexandrinum L.) as a catch crop. Experiments were planted on $10^{\text {th }}$ and $7^{\text {th }}$ of April in the first and the second seasons, respectively. Cotton planting was done by the local method of dibbling 5 to 7 seeds in each hill by hand with distance between hills was $25 \mathrm{~cm}$ apart and after 35 days of sowing thinning was carried out in order to maintain better two seedlings per hill (56000 cotton plants/fed). The experimental design was split plot design with four replicates. The four concentrations of nano zinc fertilizer were randomly assigned for main plots and the three times of foliar application were randomly assigned for sub-plots. The sub plot area was $14.4 \mathrm{~m}^{2}$ and contained six ridges of $4.0 \mathrm{~m}$ long and $60 \mathrm{~cm}$ apart. Phosphorous fertilizer was applied at a rate of $25.0 \mathrm{~kg} \mathrm{P}_{2} \mathrm{O}_{5} / \mathrm{fed}$ in form of calcium super phosphate $\left(12.5 \% \mathrm{P}_{2} \mathrm{O}_{5}\right)$ after ridging and before planting in each season. Nitrogen fertilizer was applied at a rate of $60 \mathrm{~kg} \mathrm{~N} / \mathrm{fed}$ as ammonium nitrate $(33.5 \% \mathrm{~N})$ and divided into two equal parts and applied side dressed before the first and second irrigations in each season. Potassium fertilizer was applied in form of potassium sulphate $\left(48 \% \mathrm{~K}_{2} \mathrm{O}\right)$ at a rate of $48 \mathrm{~kg} \mathrm{~K}_{2} \mathrm{O} / \mathrm{fed}$ in one dose before the second irrigation in each season. Pest and weed management were conducted as needed during the growing season, according to local practice performed at the experimental station. The first irrigation was applied after 21 day from planting irrigation, while the other irrigations were given at 15-day interval. Hand hoeing was carried out three times during the season before the first, second and third irrigations, respectively. All recommended cultural practices for growing cotton according to Agricultural Research Center recommendation were done properly.

\section{Traits studied:}

\section{A- Growth traits, yield components and yield:}

In both season, at harvest time, ten plants were randomly chosen from the two center ridges of each sup-plot to determine:

1) Plant height $(\mathrm{cm})$. The plant height was measured in $\mathrm{cm}$, from the cotyledonary node to the top of the plant at harvest and average was computed.

2) Number of sympodial branches/plant at harvest.

3) Number of opened bolls/plant. It was calculated by counting the opened bolls/plant on the above the representative plants before the first and second picking.

4) Boll weight (g). It was calculated from the following formula:

Boll weight $(\mathrm{g})=\frac{\text { Seed cotton yield } / \text { plant }(\mathrm{g})}{\text { No. of open bolls } / \text { plant at harvest }}$

5) Seed index (g). It was estimated from the average of 100 -seed weight (g) was taken at random after ginning.

6) Lint percentage (\%). The all seed cotton obtained from ten representative plants were ginned separately treatment wise with a hand ginning. Lint \% was calculated by using the following formula:

Lint percentage $(\%)=\frac{\text { Weight of lint }(\mathrm{g})}{\text { Weight of seed cotton }(\mathrm{g})} \times 100$

7) Seed cotton yield/feddan (kentar). It was estimated and transformed to kentar/feddan (feddan $=4200 \mathrm{~m}^{2}$ and kentar $=157.5 \mathrm{~kg}$ ), the seed cotton yield was picked twice; first hand picking took place on 30 and 26 September and final picking on 22 and 20 October in 2016 and 2017 , respectively, in picking from whole plants of two center ridges (including 10 plant subsamples) were selected to be picked in order to avoid border effect.

8) Lint cotton yield/fed (kentar). It was estimated and transformed to kentar/fed (kentar $=50 \mathrm{~kg}$ ), it was calculated from the following equation:

Lint cotton yield $/$ fed $($ ken $)=\frac{\text { Seed cotton yield } / \text { fed }(\text { ken }) \times 157.5 \times \text { Lint } \%}{50 \times 100}$ 


\section{B- Fiber properties:}

1) Upper half mean length $(\mathrm{mm})$.

2) Length uniformity index $(\%)$.

3) Fiber strength $(g /$ tex $)$.

4) Fiber elongation percentage (\%).

5) Micronaire value.

6) Fiber maturity ratio.

The measurement of some fiber technological properties were determined at Cotton Technology Research Division, Cotton Research Institute, Giza, Egypt, at a constant relative humidity $65 \%( \pm 2)$ and temperature $21 \mathrm{C}^{\mathrm{O}}( \pm 2)$. HVI instrument system was used to determine fiber length at Upper half means length (UHML), length uniformity index (\%), fiber strength (g/tex) and fiber elongation percentage $(\%)$ according to (A.S.T.M., D:4605-1986.). While micronaire value and fiber maturity ratio were determined using micromate instrument according to (A.S.T.M., D: 3818 - 1986).

\section{Statistical analysis:}

The analysis of variance was carried out according to the procedure described by Gomez and Gomez (1984). Data were statistically analyzed according to using the MSTAT-C Statistical Software Package (Freed, 1991). Where the F-test showed significant differences among mean of treatments, the least significant difference (L.S.D.) test at 0.05 level was used to compare between means.

\section{Results and Discussion}

\section{A- Growth traits, yield components and yield:}

Mean values of growth characters, yield components and yield for Egyptian cotton $c v$. Giza 94 as affected by concentrations and times of foliar feeding by nano zinc fertilizer as well as their interaction during 2016 and 2017 seasons, are presented in Table 2.

\section{Effect of concentrations of nano zinc fertilizer:}

Results indicated that increasing concentrations of nano zinc from the untreated control (distilled water)) up to $300 \mathrm{ppm}$ caused remarkable increments in mean values of plant height $(\mathrm{cm})$, No. of sympodial branches/plant, No. of opened bolls/plant, boll weight $(\mathrm{g})$, seed index $(\mathrm{g})$, lint percentage $(\%)$, seed cotton yield (ken/fed) and lint cotton yield (ken/fed) during the first and second seasons. But, no significant difference was noticed on mean values of all cotton traits between foliar feeding by $200 \mathrm{ppm}$ and 300 ppm nano zinc during both seasons.

The highest mean values of plant height (176.3 and $178.9 \mathrm{~cm})$, No. of sympodial branches/plant (16.87 and 17.50 branches), No. of opened bolls/plant (18.92 and 18.96 bolls), boll weight (3.612 and 3.721 g), seed index (13.09 and $13.42 \mathrm{~g}$ ), lint percentage
(39.98 and $41.22 \%)$, seed cotton yield/fed (13.39 and $13.97 \mathrm{ken})$ and lint cotton yield/fed (16.86 and 18.15 ken) were obtained by spraying 300 ppm nano zinc during the first and second seasons, respectively. While, cotton plants which received distilled water (control) significantly produced the lowest mean values of above traits during the both seasons.

The superiority rations in the 2016 season between the highest concentration of nano zinc ( 300 ppm) and each of $200 \mathrm{ppm}, 100 \mathrm{ppm}$ and distilled water (control) were $0.40,1.44$ and $7.63 \%$ for plant height; $2.49,8.91$ and $21.11 \%$ for No. of sympodial branches/plant; 2.88, 9.94 and $29.77 \%$ for No. of opened bolls/plant; 1.78, 3.89 and $14.82 \%$ for boll weight; $1.71,3.89$ and $14.82 \%$ for seed index; 0.23 , 0.55 and $3.01 \%$ for lint percentage; 5.60, 18.71 and $43.06 \%$ for seed cotton yield/fed in addition to 5.84, 19.24 and $47.25 \%$ for lint cotton yield/fed, respectively. Similar results were noticed in 2017 season, the superiority ratios with foliar spray of nano zinc at highest concentration (300 ppm) were 0.96 , 2.23 and $7.64 \%$ for plant height; 2.04, 5.36 and $25.99 \%$ for No. of sympodial branches/plant; 2.21 , 5.22 and $32.40 \%$ for No. of opened bolls/plant; 1.78 , 4.46 and $13.62 \%$ for boll weight; $2.13,4.84$ and $15.89 \%$ for seed index; $0.22,0.34$ and $3.67 \%$ for lint percentage; $4.88,12.03$ and $37.50 \%$ for seed cotton yield/fed in addition to 5.10, 12.38 and $42.58 \%$ for lint cotton yield/fed, as compared with foliar spray by nano zinc concentrations of 200 and $100 \mathrm{ppm}$ as well as distilled water (control), respectively.

Such increases in plant growth traits, yield components and yield due to higher concentration of nano zinc may be due to the role of zinc in activates enzymes and involved in protein, lipids, carbohydrates and nucleic acid metabolism. Zinc plays an important role in protein and carbohydrates syntheses. Zinc has a major role in cell defenses against ROS and as a protective factor against several chemical compositions of oxidation such as membrane lipids, protein, chlorophyll, and enzyme having SH and DNA. Zinc plays an important role as a metal component of enzymes (alcohol dehydrogenase, superoxide dismutase, carbonic anhydrase and RNA polymerase) or as a functional, structural, or regulator cofactor of a large number of enzymes.

Similar results were also obtained by Sawan et al. (2008), Ali et al. (2011), Efe and Yarpuz (2011), Abdallah and Mohamed (2013), Mousavi et al. (2013), Siskani et al. (2017), Emara (2016), Venkatachalam et al. ((2017), El-Gedwy et al. (2018), Hussein and Abou-Baker (2018) and Madbouly (2018).

\section{Effect of foliar application times:}

Results obtained revealed that mean values of plant height $(\mathrm{cm})$, No. of sympodial branches/plant, No. of opened bolls/plant, seed cotton yield (ken/fed) 
and lint cotton yield (ken/fed) were significantly differed with times of foliar application of nano zinc fertilizer (at the squaring stage, at the flowering initiation stage and at the top of flowering stage) in the first and second seasons. While, mean values of boll weight $(\mathrm{g})$, seed index $(\mathrm{g})$ and lint percentage (\%) were not significantly affected by foliar application times of nano zinc fertilizer during the both seasons.

Regarding times of foliar application effect, foliar spraying of nano zinc fertilizer at the flowering initiation stage achieved maximum estimates in mean values of plant height $(173.9$ and $175.9 \mathrm{~cm})$, No. of sympodial branches/plant (16.47 and 16.80 branches), No. of opened bolls/plant (17.79 and 17.97 bolls), seed cotton yield/fed (12.31 and $13.20 \mathrm{ken})$ and lint cotton yield/fed (15.46 and 17.10 ken) during the first and second seasons, respectively. On the other hand, the lowest mean values of plant height $(170.8$ and $173.2 \mathrm{~cm})$, No. of sympodial branches/plant (14.68 and 15.73 branches), No. of opened bolls/plant (16.69 and 16.95 bolls), seed cotton yield/fed (10.92 and $11.77 \mathrm{Ken})$ and lint cotton yield/fed (13.58 and $15.01 \mathrm{ken})$ where obtained from foliar spraying of nano zinc fertilizer at the squaring stage during the first and second seasons, respectively.

The results obtained from the first season, the superiority ratios between foliar spray of nano zinc fertilizer at the flowering initiation stage and either at the squaring stage or at the top of flowering stage were 0.81 and $1.81 \%$ for plant height; 3.45 and $12.19 \%$ for No. of sympodial branches/plant; 2.48 and $6.59 \%$ for No. of opened bolls/plant; 4.32 and $12.73 \%$ for seed cotton yield/fed in addition to 4.88 and $13.84 \%$ for lint cotton yield/fed, respectively. Similar results were noticed in the second season, the superiority ratios with foliar spray of nano zinc fertilizer at the flowering initiation stage were 1.15 and $1.56 \%$ for plant height; 2.88 and $6.80 \%$ for No. of sympodial branches/plant; 2.86 and $6.02 \%$ for No. of opened bolls/plant; 5.68 and $12.15 \%$ for seed cotton yield/fed in addition to 6.15 and $13.92 \%$ for lint cotton yield/fed as compared to foliar spay with nano zinc fertilizer at the squaring stage or at the top of flowering stage, respectively.

Many investigators came out with similar results as Sawan et al. (2008), Abdallah and Mohamed (2013), Radhika et al. (2013) and El-Gedwy et al. (2018).

\section{Effect of the interaction:}

The significant effect of the interaction between concentrations and foliar application times with nano zinc fertilizer obtained for some growth traits, yield components and cotton yield such as No. of sympodial branches/plant, No. of opened bolls/plant, seed cotton yield (ken/fed) and lint cotton yield (ken/fed) during the 2016 and 2017 seasons. While, mean values of plant height $(\mathrm{cm})$, boll weight $(\mathrm{g})$, seed index $(\mathrm{g})$ and lint percentage (\%) were not affected by the interaction.

Results noticed that, foliar spray by the highest concentration of nano zinc fertilizer (300 ppm) gave the highest interaction values for these traits under all foliar application times in the both growing seasons. Also, sowing cotton plants with foliar spray at the flowering initiation gave the highest mean values on all cotton traits in the both seasons under all concentrations of nano zinc fertilizer, while foliar spray at the squaring stage recorded the lowest mean values of all traits under all concentrations of nano zinc fertilizer in the both growing seasons.

Planting Egyptian cotton $c v$. Giza 94 which foliar spray by highest concentration of nano zinc fertilizer (300 ppm) at the flowering initiation stage significantly recorded the highest mean values of No. of sympodial branches/plant (17.75 and 18.05 branches), No. of opened bolls/plant (19.55 and 19.65 bolls), seed cotton yield/fed (14.08 and $14.91 \mathrm{ken}$ ) and lint cotton yield/fed (17.83 and $19.50 \mathrm{ken})$ in the first and second seasons, respectively. On the other hand, foliar spray by distilled water (control) at the squaring stage gave the lowest mean values of No. of sympodial branches/plant (13.23 and 13.87 branches), No. of opened bolls/plant (14.54 and 14.25 bolls), seed cotton yield/fed (9.32and $10.06 \mathrm{ken})$ and lint cotton yield/fed (11.40 and $12.60 \mathrm{ken})$ during the both seasons, respectively.

Similar results were also reported by Sawan et al. (2008), Abdallah and Mohamed (2013) and ElGedwy et al. (2018).

\section{B- Fiber properties:}

Results in Table 3 shown that mean values of some fiber properties parameters such as upper half mean length $(\mathrm{mm})$, length uniformity index $(\%)$, fiber strength (g/tex), fiber elongation percentage $(\%)$, micronaire value and fiber maturity ratio for Egyptian cotton $c v$. Giza 94 as affected by concentrations and times of foliar application with nano zinc fertilizer as well as their interaction during 2016 and 2017 seasons.

\section{Effect of concentrations of nano zinc fertilizer:}

The some measured fiber properties parameters such as upper half mean length (mm), fiber strength (g/tex), micronaire value and fiber maturity ratio were significantly increased with increasing zinc concentration in the form of nano fertilizer compared to plants receiving distilled water. 
Table 2. Effect of concentration and spraying time of nano zinc as well as their interaction on plant height (cm), No. of sympodial branches/plant, No. of opened bolls/plant, boll weight (g), seed index (g), lint percentage (\%), seed cotton yield/fed (ken) and lint cotton yield/fed (ken) of cotton during 2016 and 2017 seasons.

\begin{tabular}{|c|c|c|c|c|c|c|c|c|c|c|c|c|c|c|}
\hline \multirow[t]{2}{*}{ Treatment } & \multirow{2}{*}{$\begin{array}{c}\text { Trait } \\
\text { Season }\end{array}$} & $\begin{array}{l}\text { Plant height } \\
(\mathbf{c m})\end{array}$ & $\begin{array}{c}\text { No. of } \\
\text { sympodial } \\
\text { branches/plant }\end{array}$ & \multicolumn{2}{|c|}{$\begin{array}{l}\text { No. of opened } \\
\text { bolls/plant }\end{array}$} & \multicolumn{2}{|c|}{$\begin{array}{c}\text { Boll weight } \\
\text { (g) }\end{array}$} & \multicolumn{2}{|c|}{$\begin{array}{l}\text { Seed index } \\
\text { (g) }\end{array}$} & \multicolumn{2}{|c|}{$\begin{array}{c}\text { Lint } \\
\text { percentage } \\
(\%)\end{array}$} & \multicolumn{2}{|c|}{$\begin{array}{c}\text { Seed cotton } \\
\text { yield/fed } \\
(\text { ken })\end{array}$} & $\begin{array}{l}\text { Lint cotton } \\
\text { yield/fed } \\
\text { (ken) }\end{array}$ \\
\hline & & 2016 & 2016 & 201 & 2017 & 201 & 2017 & 2016 & 2017 & 2016 & 2017 & 2016 & 201 & 2016 \\
\hline
\end{tabular}

Nano zinc concentration (ppm)

\begin{tabular}{|c|c|c|c|c|c|c|c|c|c|c|c|c|c|c|c|c|}
\hline Control (Distilled Water) & 163.8 & 166.2 & 13.93 & 13.89 & 14.58 & 14.32 & 3.157 & 3.275 & 11.40 & 11.58 & 38.81 & 39.76 & 9.36 & 10.16 & 11.45 & 12.73 \\
\hline 100 & 173.8 & 175.0 & 15.49 & 16.61 & 17.21 & 18.02 & 3.435 & 3.562 & 12.60 & 12.80 & 39.76 & 41.08 & 11.28 & 12.47 & 14.14 & 16.15 \\
\hline 200 & 175.6 & 177.2 & 16.46 & 17.15 & 18.39 & 18.55 & 3.549 & 3.656 & 12.87 & 13.14 & 39.89 & 41.13 & 12.68 & 13.32 & 15.93 & 17.27 \\
\hline 300 & 176.3 & 178.9 & 16.87 & 17.50 & 18.92 & 18.96 & 3.612 & 3.721 & 13.09 & 13.42 & 39.98 & 41.22 & 13.39 & 13.97 & 16.86 & 18.15 \\
\hline $5 \%$ & 1.5 & 1.4 & 0.39 & 0.32 & 0.45 & 0.41 & 0.214 & 0.192 & 0.21 & 0.19 & 0.26 & 0.23 & 0.31 & 0.34 & 0.39 & 0.41 \\
\hline
\end{tabular}

L.S.D at $5 \%$

1.5

At the squaring stage

At the flowering initiation

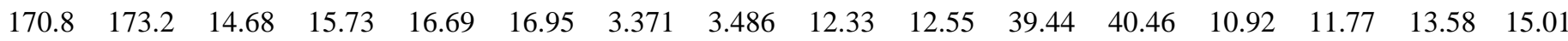

At the top of flowering

$\begin{array}{llllllllllllllllll}173.9 & 175.9 & 16.47 & 16.80 & 17.79 & 17.97 & 3.492 & 3.619 & 12.69 & 13.00 & 39.79 & 41.05 & 12.31 & 13.20 & 15.46 & 17.10\end{array}$

L.S.D at $5 \%$

\begin{tabular}{lllllllllllllllll}
172.5 & 173.9 & 15.92 & 16.33 & 17.36 & 17.47 & 3.452 & 3.555 & 12.45 & 12.66 & 39.60 & 40.89 & 11.80 & 12.49 & 14.74 & 16.11 \\
\hline
\end{tabular}

Interaction effect

Control At the squaring stage

$\begin{array}{llllllllllllllll}1.9 & 1.6 & 0.42 & 0.39 & 0.51 & 0.47 & \text { N.S. } & \text { N.S. } & \text { N.S. } & \text { N.S. } & \text { N.S. } & \text { N.S. } & 0.36 & 0.41 & 0.44 & 0.53\end{array}$

(Distilled At the flowering initiation

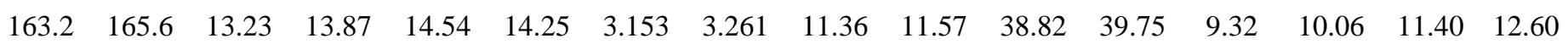

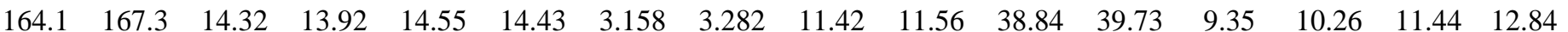

Water) At the top of flowering

$\begin{array}{lllllllllllllllll}164.2 & 165.7 & 14.25 & 13.87 & 14.65 & 14.29 & 3.159 & 3.283 & 11.43 & 11.62 & 38.77 & 39.81 & 9.42 & 10.17 & 11.50 & 12.75\end{array}$

At the squaring stage

$\begin{array}{lllllllllllllllll}171.7 & 173.6 & 14.35 & 15.98 & 16.62 & 17.25 & 3.356 & 3.464 & 12.35 & 12.73 & 39.49 & 40.61 & 10.51 & 11.44 & 13.07 & 14.63\end{array}$

$100 \mathrm{ppm}$ At the flowering initiation

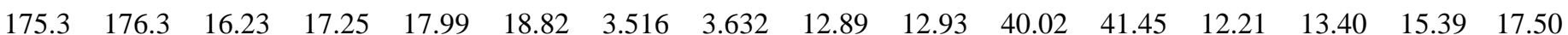

At the top of flowering

$\begin{array}{lllllllllllllllll}174.3 & 175.2 & 15.89 & 16.59 & 17.02 & 17.98 & 3.432 & 3.591 & 12.56 & 12.75 & 39.76 & 41.19 & 11.13 & 12.57 & 13.94 & 16.31\end{array}$

At the squaring stage

$\begin{array}{lllllllllllllllll}173.5 & 175.2 & 15.24 & 16.22 & 17.57 & 18.03 & 3.457 & 3.567 & 12.73 & 12.87 & 39.71 & 40.68 & 11.63 & 12.49 & 14.55 & 16.00\end{array}$

200 ppm At the flowering initiation

At the top of flowering

$\begin{array}{lllllllllllllllll}177.9 & 179.8 & 17.57 & 17.97 & 19.05 & 18.99 & 3.635 & 3.765 & 13.11 & 13.54 & 40.11 & 41.49 & 13.59 & 14.21 & 17.17 & 18.57\end{array}$

At the squaring stage

$\begin{array}{lllllllllllllllll}175.3 & 176.5 & 16.56 & 17.25 & 18.55 & 18.63 & 3.554 & 3.635 & 12.76 & 13.02 & 39.86 & 41.23 & 12.81 & 13.27 & 16.08 & 17.23\end{array}$

$300 \mathrm{ppm}$ At the flowering initiation

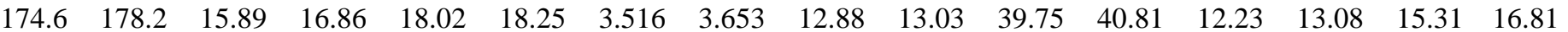

At the top of flowering

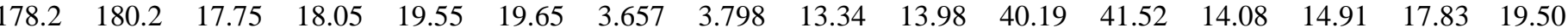

L.S.D at $5 \%$

\begin{tabular}{lllllllllllllllll}
176.2 & 178.2 & 16.98 & 17.59 & 19.20 & 18.98 & 3.664 & 3.712 & 13.05 & 13.25 & 39.99 & 41.32 & 13.85 & 13.93 & 17.45 & 18.13 \\
\hline $\mathbf{N . S .}$ & $\mathbf{N . S .}$ & $\mathbf{0 . 7 3}$ & $\mathbf{0 . 6 8}$ & $\mathbf{0 . 8 8}$ & $\mathbf{0 . 8 1}$ & $\mathbf{N . S .}$ & $\mathbf{N . S .}$ & $\mathbf{N . S .}$ & $\mathbf{N . S .}$ & $\mathbf{N . S .}$ & $\mathbf{N . S .}$ & $\mathbf{0 . 6 2}$ & $\mathbf{0 . 7 1}$ & $\mathbf{0 . 7 6}$ & $\mathbf{0 . 9 2}$ \\
\hline
\end{tabular}


The highest mean values of upper half mean length (34.34 and $34.45 \mathrm{~mm})$, fiber strength (44.86 and $45.11 \mathrm{~g} /$ tex $)$, micronaire value (4.300 and 4.367) and fiber maturity ratio $(0.971$ and 0.970$)$ were obtained by spraying $300 \mathrm{ppm}$ nano zinc fertilizer during the first and second seasons, respectively. While, cotton plants which received distilled water significantly produced the lowest mean values of upper half mean length (33.34 and $33.53 \mathrm{~mm})$, fiber strength (43.63 and $43.74 \mathrm{~g} /$ tex $)$, micronaire value (4.122 and 4.167) and fiber maturity ratio (0.942 and 0.949 ) in the both seasons, respectively.

Such increases in fiber properties due to higher concentration of nano zinc may be due to the role of zinc on fundamental metabolic reactions and acceleration protein synthesis which affects fiber development and formation.

Many investigators came out with similar results as Sawan et al. (2008), Ali et al. (2011), Abdallah and Mohamed (2013), Mousavi et al. (2013), Emara (2016), El-Gedwy et al. (2018) and Madbouly (2018).

\section{Effect of foliar application times:}

Regarding results in Table 3 it could be noticed that there were significant differences among the three foliar application times with nano zinc fertilizer (at the squaring stage, at the flowering initiation stage and at the top of flowering stage) on some fiber properties traits such as mean values of upper half mean length $(\mathrm{mm})$ and fiber strength $(\mathrm{g} / \mathrm{tex})$ during the both seasons. While, mean values of length uniformity index (\%), fiber elongation percentage $(\%)$, micronaire value and fiber maturity ratio were not affected by foliar application times with nano zinc fertilizer during the both seasons.

The highest mean values of upper half mean length (34.07 and $34.32 \mathrm{~mm}$ ), and fiber strength (44.63 and $44.73 \mathrm{~g} /$ tex) in 2016 and 2017 seasons, respectively were recorded form foliar spray of nano zinc fertilizer at the flowering initiation stage. Likewise, the lowest mean values of upper half mean length (33.71 and $33.78 \mathrm{~mm}$ ), and fiber strength (44.23 and $44.43 \mathrm{~g} /$ tex) in the first and second seasons, respectively were gained from foliar spray of nano zinc fertilizer at the squaring stage of cotton growths.

Many investigators came out with similar results as Sawan et al. (2008), Abdallah and Mohamed (2013), Radhika et al. (2013) and El-Gedwy et al. (2018).

\section{Effect of the interaction:}

Results revealed that some fiber properties, i.e. mean values of upper half mean length $(\mathrm{mm})$ and fiber strength (g/tex) of Egyptian cotton $c v$. Giza 94 were significantly affected by the interaction between concentrations and foliar application times with nano zinc fertilizer during 2016 and 2017 seasons. But, mean values of length uniformity index (\%), fiber elongation percentage $(\%)$, micronaire value and fiber maturity ratio were not significantly affected by the interaction during the two seasons.

Results noticed that, spraying $300 \mathrm{ppm}$ nano zinc fertilizer gave the highest interaction values for fiber properties traits under all times of foliar application in the both growing seasons. Also, sowing cotton plants with spraying nano zinc fertilizer at the flowering initiation stage gave the highest mean values on all fiber properties traits in the both seasons under all concentrations of nano zinc fertilizer, while foliar spray at the squaring stage recorded the lowest mean values off all traits under all concentrations of nano zinc fertilizer in the both growing seasons. The highest mean values of upper half mean length (34.81 and $34.87 \mathrm{~mm}$ ) and fiber strength (45.07 and 44.27 $\mathrm{g} /$ tex) in 2016 and 2017 seasons, respectively were obtained by spraying $300 \mathrm{ppm}$ nano zinc fertilizer at the flowering initiation stage of cotton plants. Likewise, the lowest mean values of upper half mean length (33.32 and $33.42 \mathrm{~mm}$ ) and fiber strength (43.63 and $43.73 \mathrm{~g} /$ tex) in the both seasons, respectively were recorded from cotton plants which received distilled water (control) at the squaring stage of cotton plants .

Similar results were also reported by Sawan $\boldsymbol{e t}$ al. (2008), Abdallah and Mohamed (2013) and ElGedwy et al. (2018).

\section{Conclusion}

Based on the previous results it could be concluded that, planting Egyptian cotton $c v$. Giza 94 with foliar feeding by nano zinc at concentration of $300 \mathrm{ppm}$ during the flowering initiation stage produced good yield and fiber properties traits under the conditions of Kafr El-Sheikh location. 
Table 3. Effect of concentration and spraying time of nano zinc as well as their interaction on fiber technological properties during 2016 season during 2016 and 2017 seasons.

\begin{tabular}{|c|c|c|c|c|c|c|c|c|c|c|c|c|c|}
\hline \multirow{2}{*}{\multicolumn{2}{|c|}{ Treatment }} & \multicolumn{2}{|c|}{$\begin{array}{c}\text { Upper half mean } \\
\text { length } \\
(\mathbf{m m})\end{array}$} & \multicolumn{2}{|c|}{$\begin{array}{c}\text { Length uniformity } \\
\text { index } \\
(\%)\end{array}$} & \multicolumn{2}{|c|}{$\begin{array}{c}\text { Fiber Strength } \\
(\mathrm{g} / \mathrm{tex})\end{array}$} & \multicolumn{2}{|c|}{$\begin{array}{c}\text { Fiber elongation } \\
\text { percentage } \\
(\%)\end{array}$} & \multicolumn{2}{|c|}{ Micronaire Value } & \multicolumn{2}{|c|}{ Fiber maturity ratio } \\
\hline & & 2016 & 2017 & 2016 & 2017 & 2016 & 2017 & 2016 & 2017 & 2016 & 2017 & 2016 & 2017 \\
\hline \multicolumn{14}{|c|}{ Nano zinc concentration (ppm) } \\
\hline \multicolumn{2}{|c|}{ Control (Distilled Water) } & 33.34 & 33.53 & 88.24 & 88.33 & 43.63 & 43.74 & 7.215 & 7.333 & 4.122 & 4.167 & 0.942 & 0.949 \\
\hline \multicolumn{2}{|c|}{100} & 33.85 & 33.90 & 88.65 & 88.71 & 44.55 & 44.57 & 7.278 & 7.411 & 4.234 & 4.244 & 0.960 & 0.958 \\
\hline \multicolumn{2}{|c|}{200} & 34.10 & 34.39 & 88.81 & 89.02 & 44.69 & 44.88 & 7.400 & 7.489 & 4.234 & 4.267 & 0.966 & 0.967 \\
\hline \multicolumn{2}{|c|}{300} & 34.34 & 34.45 & 88.93 & 89.10 & 44.86 & 45.11 & 7.422 & 7.511 & 4.300 & 4.367 & 0.971 & 0.970 \\
\hline \multicolumn{2}{|c|}{ L.S.D at 5\% } & 0.12 & 0.10 & N.S. & N.S. & 0.07 & 0.05 & N.S. & N.S. & 0.070 & 0.068 & 0.012 & 0.013 \\
\hline \multicolumn{14}{|c|}{ Spraying time } \\
\hline \multicolumn{2}{|c|}{ At the squaring stage } & 33.71 & 33.78 & 88.56 & 88.65 & 44.23 & 44.43 & 7.281 & 7.400 & 4.167 & 4.225 & 0.956 & 0.959 \\
\hline \multicolumn{2}{|c|}{ At the flowering initiation } & 34.07 & 34.32 & 88.74 & 88.92 & 44.63 & 44.73 & 7.381 & 7.458 & 4.250 & 4.300 & 0.963 & 0.963 \\
\hline \multicolumn{2}{|c|}{ At the top of flowering } & 33.94 & 34.10 & 88.68 & 88.80 & 44.44 & 44.58 & 7.325 & 7.450 & 4.250 & 4.259 & 0.960 & 0.962 \\
\hline \multicolumn{2}{|c|}{ L.S.D at $5 \%$} & 0.15 & 0.13 & N.S. & N.S. & 0.08 & 0.07 & N.S. & N.S. & N.S. & N.S. & N.S. & N.S. \\
\hline \multicolumn{14}{|c|}{ Interaction effect } \\
\hline \multirow{4}{*}{$\begin{array}{c}\text { Control } \\
\text { (Distilled } \\
\text { Water) }\end{array}$} & At the squaring stage & 33.32 & 33.42 & 88.23 & 88.33 & 43.63 & 43.73 & 7.223 & 7.333 & 4.100 & 4.167 & 0.943 & 0.950 \\
\hline & At the flowering initiation & 33.35 & 33.62 & 88.24 & 88.32 & 43.64 & 43.75 & 7.223 & 7.333 & 4.100 & 4.167 & 0.940 & 0.947 \\
\hline & At the top of flowering & 33.34 & 33.54 & 88.24 & 88.34 & 43.63 & 43.75 & 7.200 & 7.333 & 4.167 & 4.167 & 0.942 & 0.949 \\
\hline & At the squaring stage & 33.81 & 33.87 & 88.55 & 88.43 & 44.21 & 44.52 & 7.267 & 7.367 & 4.167 & 4.233 & 0.957 & 0.957 \\
\hline \multirow[t]{3}{*}{100 ppm } & At the flowering initiation & 33.87 & 33.92 & 88.73 & 88.97 & 44.87 & 44.67 & 7.300 & 7.433 & 4.267 & 4.267 & 0.963 & 0.960 \\
\hline & At the top of flowering & 33.86 & 33.91 & 88.66 & 88.73 & 44.56 & 44.53 & 7.267 & 7.433 & 4.267 & 4.233 & 0.961 & 0.958 \\
\hline & At the squaring stage & 33.83 & 33.91 & 88.67 & 88.91 & 44.46 & 44.53 & 7.300 & 7.433 & 4.167 & 4.233 & 0.960 & 0.963 \\
\hline \multirow[t]{3}{*}{200 ppm } & At the flowering initiation & 34.26 & 34.86 & 88.95 & 89.15 & 44.92 & 45.21 & 7.500 & 7.533 & 4.267 & 4.300 & 0.971 & 0.971 \\
\hline & At the top of flowering & 34.22 & 34.39 & 88.82 & 89.01 & 44.68 & 44.89 & 7.400 & 7.500 & 4.267 & 4.267 & 0.966 & 0.968 \\
\hline & At the squaring stage & 33.87 & 33.93 & 88.77 & 88.93 & 44.63 & 44.92 & 7.333 & 7.467 & 4.233 & 4.267 & 0.963 & 0.965 \\
\hline \multirow[t]{2}{*}{300 ppm } & At the flowering initiation & 34.81 & 34.87 & 89.04 & 89.25 & 45.07 & 45.27 & 7.500 & 7.533 & 4.367 & 4.467 & 0.977 & 0.973 \\
\hline & At the top of flowering & 34.35 & 34.55 & 88.99 & 89.11 & 44.89 & 45.15 & 7.433 & 7.533 & 4.300 & 4.367 & 0.972 & 0.972 \\
\hline \multicolumn{2}{|c|}{ L.S.D at 5\% } & 0.26 & 0.23 & N.S. & N.S. & 0.14 & 0.12 & N.S. & N.S. & N.S. & N.S. & N.S. & N.S. \\
\hline
\end{tabular}




\section{References}

Abdallah, A. M. and H. F.Y. Mohamed (2013). Effect of foliar application of some micronutrients and growth regulators on some Egyptian cotton cultivars. J. Appl. Sci. Res., 9 (6): 3497-3507.

Ali, L.; M. Ali and Q. Mohyuddin (2011). Effect of foliar application of zinc and boron on seed cotton yield and economics in cotton-wheat cropping pattern. J. Agric. Res., 49 (2): 173-180.

American stander for testing materials (1986). D: 1578-1967, D: 1425 \& 2256 -1984, D-3818 \& D4605 -1986. USA.

Efe, L. and E. Yarpuz (2011). The effect of zinc application methods on seed cotton yield, lint and seed quality of cotton (Gossypium hirsutum L.) in east Mediterranean region of Turkey. Afri. J. Biot., 10: 8782-8789.

Egyptian Cotton Gazette (2017). Alcotexa. 149: 51.

El-Gedwy, E. M. M.; A. E. M. Gadallh and R. M. Abdel-Twab (2018). Response of some Egyptian cotton cultivars to foliar spray by some microelements. Annals of Agric. Sci., Moshtohor, 56 (4): 965 - 974.

Emara, M. A. A. (2016). Influence of potassium fertilization and spraying of zinc and manganese on cotton growth and productivity. J. Plant Production, Mansoura Univ., 7 (10): 1115 - 1125.

Freed R. D. (1991). MSTATC Microcomputer Statistical Program. Michigan State University, East Lansing, Michigan, USA.

Gomez, K. A. and A. A. Gomez (1984). Statistical Procedures for Agricultural Research. 2nd, (ed). John Wiley and Sons, NY, U.S.A.

Hussein, M. M. and N. H. Abou-Baker (2018). The contribution of nano-zinc to alleviate salinity stress on cotton plants. R. Soc.open sci. 5: 171809. http://dx.doi.org/10.1098/rsos.171809.
Jackson, M. L. (1973). Soil Chemical Analysis, Prentice Hall of India Pvt. Ltd. New Delhi.

Lindsay, W. L. and W. A. Norvell (1978). Development of DTPA soil test for Zinc, Iron, Manganese and Copper Soil Sci., 42: 241-428.

Madbouly, A. K. (2018). Nanoparticles as novel plant growth promoters. Novel Res. Microbiology J., 2 (4): 61-64.

Mousavi, S. R.; M. Galavi and M Rezaei (2013). Zinc (Zn) Importance for crop production - a review. Intl. J. Agron. Plant Prod.., 4 (1), 64-68.

Radhika, K.; S. Hemalatha; S. P. Katharine; S. Maragatham and A. Kanimozhi (2013). Foliar application of micronutrinets in cotton - a review. Res. Rev. J. Agric. Allied Sci., 2 (3): 23-29.

Sawan, Z. M.; M. H. Mahmoud and A. H. ElGuibali (2008). Influence of potassium fertilization and foliar application of zinc and phosphorus on growth, yield components, yield and fiber properties of Egyptian cotton (Gossypium barbadense L.). J. Plant Ecology, 1, (4): 259-270.

Siskani, A.; M. Seghatoleslami and G. Moosavi (2017). Effect of deficit irrigation and nano fertilizers on yield and some morphological traits of cotton. Biol. For. Int. J., 7 (1): 1710-1715.

Venkatachalam, P.; N. Priyanka; K. Manikandan; I. Ganeshbabu; P. Indiraarulselvi; N. Geetha; K. Muralikrishna; R. C. Bhattacharya; M. Tiwari; N. Sharma and S. V. Sahi (2017). Enhanced plant growth promoting role of phycomolecules coated zinc oxide nanoparticles with P supplementation in cotton (Gossypium hirsutum L.). Plant Phys. Bioch., 110: 118-127.

Wang, C.; K. Luo; Z. Zhang; Y. Wu; J. Zhang and S. Chen ( 2016. Removal of As (III) and As (V) from aqueous solutions using nanoscale zero valent iron-reduced graphite oxide modified composites. J. Haz. Mate., 268: 124-131. 


\title{
ميعاد رش تركيزات الزنك في صورة النانو وعلاقته بمحصول وجودة صنف القطن المصري جيزة 94
}

\author{
* السعيد محمد محمود الجدوي * ـ أبويكر إبراهيم محمود جاد الله

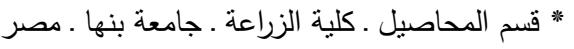

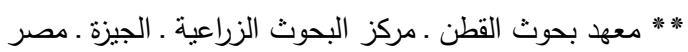

أقيمت تجربتان حقليتان بأرض طينية بمزرعة محطة البحوث الزراعية بسخا (محافظة كفر الثيخ) مركز البحوث الزراعية ـ الجيزة ـ مصر

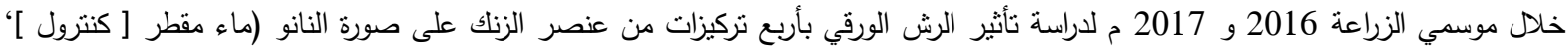
100 جزء في المليون، 200 جزء في المليون و 300 جزء في المليون) عند ثلاث مراحل مختلفة من نمو القطن (مرحلة الوسواس، مرحلة بداية التزهير و مرحلة قمة التزهير ) على النمو، مكونات المحصول، المحصول وخصائص التيلة في صنف القطن المصري جيزة 94. التصميم التجريبي المستخدم هو قطع منشقة مرة واحدة في أربع مكررات مع توزيع تركيزات الزنكل عشوائياً في القطع الرئيسية ومراحل الرش المختلفة إعتباطياً في القطع الفرعية.

ويمكن تلخيص أهم النتائج فيما يلي:.

'أشارت النتائج أن متوسط قيم صفات إرتفاع النبات (سم)' عدد الأفرع الثمرية/نبات، عدد اللوز المتفتح/نبات، وزن اللوزة (جم) دليل البذرة

(جم)' تصافي الحيج (\%)' محصول القطن الزهر /فدان (قنطار)' محصول القطن الثعر/فدان (قنطار)' طول أطول الثعيرات (مم)' منانة الشعبرات (جم/تكس)، قراءة الميكرونير ونضج الثعيرات زادت معنوياً بزيادة نركيز عنصر الزنك في صورة النانو مقارنتأ برش النباتات بالماء طول

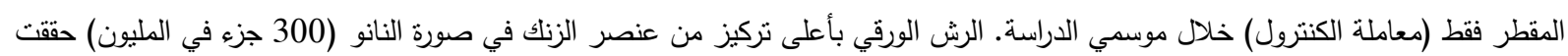
أفضل متوسط قيم للصفات السابقة خلال موسمس الدراسة. أوضحت النتائج أن الرش الخضري عند مرحلة بداية التزهير كانت أفضل المراحل حيث أعطت معنوياً أعلى منوسط للقيم في صفات

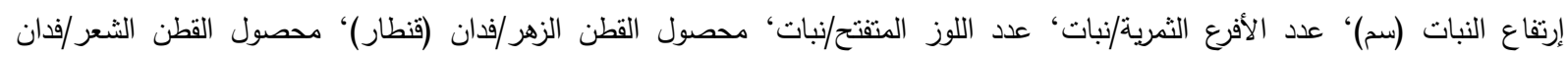
(قنطار)، طول أطول الثعيرات (مم) و منانة الثعيرات (جم/تكس) تلتها معاملة الرش الخضري عند مرحلة قمة التزهير ثم الرش الخضري عند مرحلة الوسواس في كلا الموسمين. الرش الخضري بأعلى تركيز من عنصر الزنك في صورة النانو (300 جزء في المليون) عند مرحلة بداية تزهير نباتات القطن معنوياً

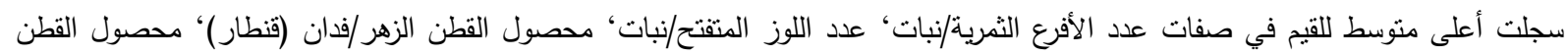

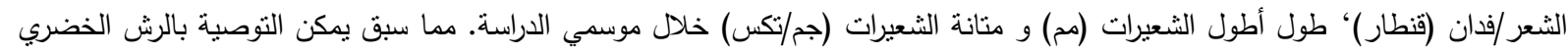

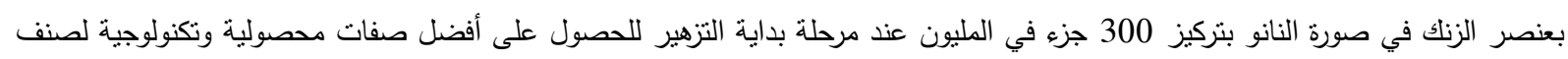
القطن المصري جيزة 94 وذلك تحت ظروف منطقة كفر الثيخ.. 